\title{
Surface Modification of Ti-6Al-4V Alloy By Anodization Technique at Low Potential to Produce Oxide Layer
}

\author{
Franciska Pramuji Lestari ${ }^{1 \mathrm{a}}$, Yeni Rian Sari ${ }^{2 \mathrm{~b}}$, Fendy Rokhmanto ${ }^{1 \mathrm{c}}$, Talitha Asmaria ${ }^{1 \mathrm{~d}}$, Andika Widya Pramono ${ }^{1 \mathrm{e}}$, \\ Tutun Nugraha ${ }^{2 f}$, Aprilia Erryani ${ }^{1 \mathrm{~g}}$, Yudi Nugraha Thaha ${ }^{\mathrm{lh}}$ and Ika Kartika ${ }^{1 \mathrm{i}}$ \\ la,c,d,e,g,h,ij Research Center for Metallurgy and Materials, Indonesian Institute of Sciences (LIPI) \\ Kawasan PUSPIPTEK Gd. 470 Tangerang Selatan, Banten, 15314 \\ $2 \mathrm{~b}, \mathrm{f}$ International Universeit of Liaison Indonesia (IULI) \\ The Breeze, BSD City, Tangerang, Banten, 15345
}

\begin{tabular}{l} 
Article Info \\
\hline Article History: \\
Received \\
Revised \\
Accepted \\
\hline
\end{tabular}

\section{Keywords:}

Calibration

Positive Pressure

Vacuum Pressure

Leakage Test

\begin{abstract}
Due to their excellent biocompatibility, titanium alloys are tremendously as implants used, since relatively low modulus, corrosion resistance, and good fatigue strength. The biocompatibility, comes from the formation of natural Titanium dioxide $\left(\mathrm{TiO}_{2}\right)$ layer. Therefore, $\mathrm{TiO} 2$ layer growth surface alteration is frequently applied to improve biological, chemical, and mechanical properties. $\mathrm{TiO}_{2}$ nanostructures are obtained under self-organization conditions by electrochemical anodization of $\mathrm{Ti}$ 6AI-4V. Parameters of anodization such as anodization time, voltage and addition of thiourea were evaluated in the composition of the $\mathrm{H3PO4}+\mathrm{NH} 4 \mathrm{~F}$ solution. The morphology and elements of the Ti alloys surface were analyzed by Scanning Electron Microscopy (SEM) and Energy-Dispersive Spectroscopy (EDS), whereas potentiodynamic polarization and electrochemical impedance spectroscopy (EIS) were used to evaluate the $\mathrm{TiO}_{2}$ layer in corrosion resistance. The results showed that the anodized Ti-6Al-4V alloy E-corr imcreased as the anodization voltage increased. Titanium alloy anodized using $12 \mathrm{~V}$ during 2 hours with $\mathrm{H}_{3} \mathrm{PO}_{4}+\mathrm{NH}_{4} \mathrm{~F}$ without thiourea solution had the thickest of oxide layer and highest corrosion resistance. Higher applied voltages have been shown to increase the deposition rate and coating thickness. Addition of thiourea has a definite effect on the inhibition of oxide layer of titanium. In order to produce the optimum titanium surface, the required applied anodization voltage and addition of volume thiourea is necessary.
\end{abstract}

\author{
Corresponding Author: \\ fran011@lipi.go.id, \\ Research Center for Metallurgy and Materials \\ Indonesian Institute of Sciences
}

This work is an open-access article and licensed under a Creative Commons Attribution-ShareAlike 4.0 International License (CC BY-SA 4.0).

\section{INTRODUCTION}

Because of their superior mechanical properties, titanium and its alloy are extensively utilized as metallic biomaterials, especially for load-bearing applications, [1][2]. In addition, they also have outstanding biocompatibility with tissue, bones, blood as well as excellent corrosion resistance [2]. The corrosion resistance emerges from the creation of a natural oxide layer, which consists primarily of $\mathrm{TiO}_{2}$, on the titanium surfaces when it touches with the air [3][4]. Titanium on the surface of the recovered clip aneurysm, oxide, and calcium were found, which suggested the development of layers resistant to corrosion. Aneurysm Titanium-alloy clips maintain their mechanical properties for a long period in the human cranium

[5]. Unfortunately, this natural oxide film is very thin, resulting in implant wear and low bone-bonding capacity [2][6]. Longterm implantation of titanium-based implants can facilitate progressive debris release and may cause patient autoimmune reactions [7]. It can be said that titanium and titanium alloys have poor osseointegration characteristics [2][6]. It has been shown from previous studies that the self-ordered oxide layer can contribute to improved bioactivity and osseointegration of the material [8]. 
Various techniques of alteration, including acid etching, blasting, grit, plasma spraying, and anodization, have been attempted. The effect of the plasma spray coating is that titanium fragments are often present in the bone next to these implants. In the liver, aggregates of small macrophage, and even in para-aortic lymph nodes, the presence of ions from metallic wear from endosseous implants was also reported [9]. Because of the potentially dangerous effect in local and systemic carcinogenic, the ions from metal as implant emitted, might be the result of fretting, dissolution, or wear, and maybe a source of concern. Grit blasting is another procedure and Alumina or $\mathrm{Al}_{2} \mathrm{O}_{3}$ is mostly using as a blasting medium and creates the roughness of surface that varies with granulometry as blasting media. However, often after ultrasonic washing, sterilization, and acid passivation, the blasting material was always trapped in the implant surface and debris persists. As insoluble in acid, alumina is impossible to extract from the surface of the titanium. Alumina particles have, in some cases, been released into the surrounding tissues and have interacted with implant osseointegration. In addition, the heterogeneity chemical of the implant surfaces can minimize titanium's excellent corrosion resistance in a body environment [10]. Acid-etching is another technique that develops micro pits on titanium surfaces. Chemical treatments may reduce titanium's mechanical properties. Acid-etching, for example, will lead to titanium hydrogen embrittlement, producing micro-cracks on the surface which may decrease the resistance implant fatigue [11].

In contrast to machined surfaces, anodized surfaces result in bone reaction reinforcement with higher values for histomorphometric and biomechanical measurements. To clarify this osseointegration, mechanical interlocking, and biochemical bonding by bone growth in pores, two mechanisms were proposed [12]. Anodizing, used by oxidation as which is an electrolytic process to shape a layer coating on the surface of the metal, is an easy and not expensive use of these processes [13]. The roughness of porosities on the titanium surface could also be produced by anodization technique and this could increase the bone-implant formation and increase better osseointegration. The study of clinical has shown that anodization of titanium with an oxide coating and a rough porous surface can facilitate better and faster tissue growth of bones on titanium implants [14]. The natural oxide layer is thinner than an oxide layer formed by anodization [15]. Among others, the anodization process is considered to be the best and cheapest process. In addition, the titanium anodizing nanostructure's surface is often simple to monitor the changes of the anodization parameters such as anodization time, potential, and electrolyte [8][16]. In this study, the Ti-6Al-4V titanium-based alloy was anodized for 1 hour and 2 hours at the low potential in the electrolyte comprising $\mathrm{H}_{3} \mathrm{PO}_{4}, \mathrm{NH}_{4} \mathrm{~F}$, and thiourea. The procedure was then accompanied by annealing at $500{ }^{\circ} \mathrm{C}$ for 2 hours to form the anatase on the surface. A thin and dense oxide layer with an amorphous structure, usually produces at a low voltage of anodizing, while a high voltage of anodizing above the breakdown limit results in a thick porous oxide layer crystalline structure with the oxide layer thickness equal to the voltage that used [17]. Ions of electrolyte is another value of anodization which able to diffuse through the oxide layer and combine with it [18]. In addition, biologically active organism, such as phosphate ions, which are capable of inducing the proliferation of cell on anodized surfaces, can be found in the oxide coating layer [19]. Considering the low risk and cost-effective, low potential was used [20].

The present research was therefore intended to examine surface morphology and corrosion activity of the Ti-6Al-4V alloy after low voltage anodization. The surface morphological properties and composition of the anodized oxide film were defined using the Scanning Electron Microscope ( SEM). To determine the corrosion resistance in the Hank solution containing amvastatine and amlodipine, electrochemical impedance spectroscopy (EIS) as well as linear polarization were used. In patients with a elevated risk of, coronary heart disease, high blood pressure and diabetes, amvastatin and amlodipine were used to study the efficacy of implants [21].

\section{MATERIALS AND METHODS}

Ti-6Al-4V ingots were obtained from laboratory of Metallurgical and Material Research Center - LIPI, PUSPIPTEK. The ingots were then cut using a wire cut into cylindrical shape with the diameter of $1 \mathrm{~cm}$ and then drilled. After that, all of the samples were grinded manually using silicon carbide (SiC) paper from grit 180, 220, 400, 1200, 1500 and 2000. Before carrying out the anodization process, the samples were washed using ultrasonic bath in acetone for 10 minutes, ethanol for 10 minutes and aquadest water for 10 minutes. The samples then dried using a hotplate for 24 hours.

Starting the anodization procedure, two types of aqueous electrolyte were prepared. First electrolyte consisted of $1 \mathrm{M}$ of $\mathrm{H}_{3} \mathrm{PO} 4$ and $1 \mathrm{M}$ of $\mathrm{NH}_{4} \mathrm{~F}$ whereas the second electrolyte contained $1 \mathrm{M}$ of $\mathrm{H}_{3} \mathrm{PO}_{4}, 1 \mathrm{M}$ of $\mathrm{NH}_{4} \mathrm{~F}$ and $0.5 \mathrm{M}$ of thiourea. The magnetic stirrer was used to homogenize the mixture during electrolyte preparation. The anodization process was conducted at room temperature, with the platinum sheet as cathode and the samples as anode. The anodization period was set for 1 hours and 2 hours with the applied voltage of $3 \mathrm{~V}$ and $12 \mathrm{~V}$.

After anodization, the samples were rinsed with aquadest water to remove the remaining contaminant from electrolyte and then dried for 24 hours in a hotplate. At the end, the samples were then annealed in a vacuum furnace at $500^{\circ} \mathrm{C}$ for 2 hours for crystallization with the heating rate of $5^{\circ} \mathrm{C}$ per minute. It was then followed by cooling process inside the furnace.

To analyze the thickness of the obtained nanotubes, (SEM) scanning electron microscopy (Jeol, type jsm 6390A) was performed. To obtain the image, the magnification of 50x, 200x, 500x, 1000x (secondary electrons and backscattered electrons mode), was used. EDX mapping was carried out to investigate the containing major elements of the samples. Electrochemical impedance spectroscopy (EIS) and linear polarization were performed using Autolab AUT87891 Potentiostat. The three-electrode electrochemical cell were connected to the potentiostat which consists of reference electrode (RE) using $\mathrm{Ag} / \mathrm{AgCl}$, counter electrode (CE) using 
A

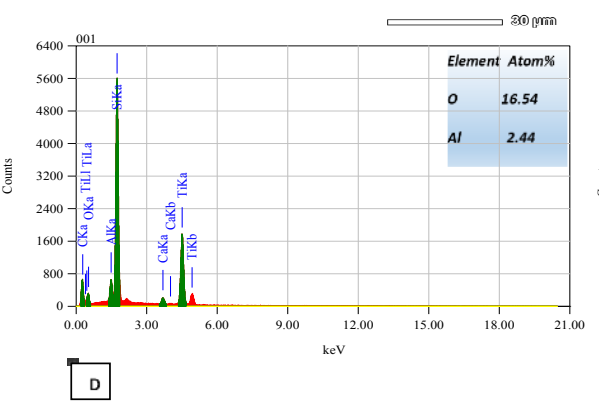

502

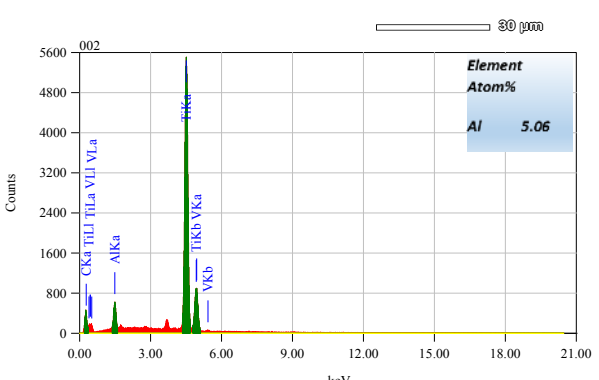

G

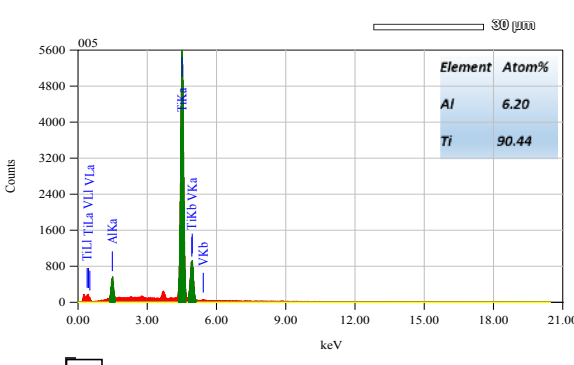

$\mathrm{E}$

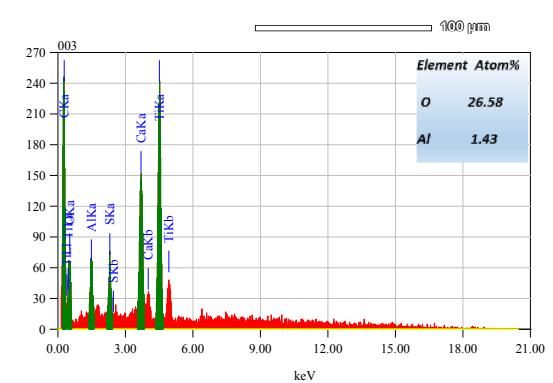

H

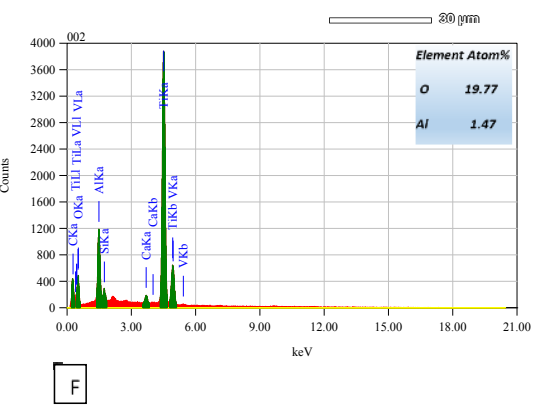

마만

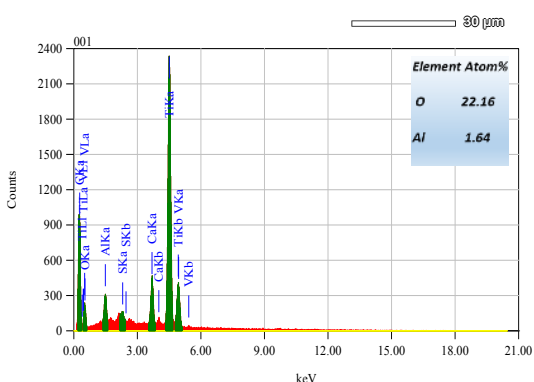

민.
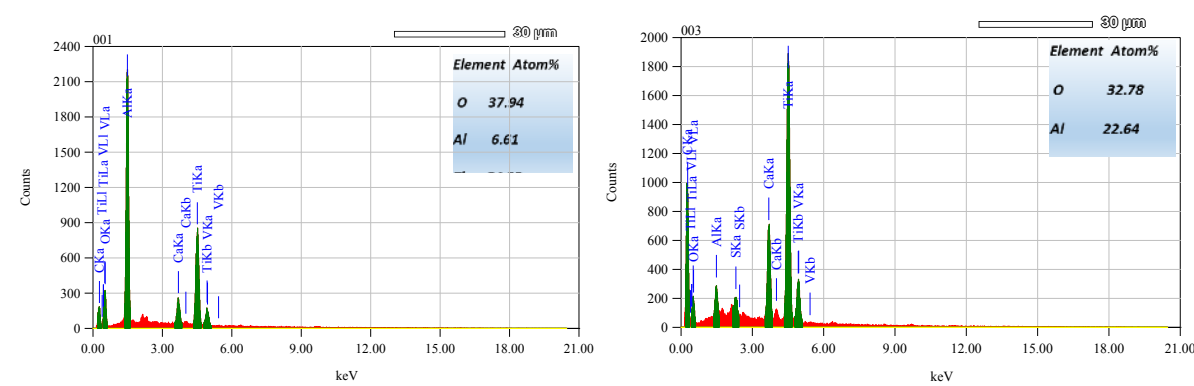

Fig. 1. SEM Morphology and EDS Result of oxide layer Ti-Al-V alloys (Potential, time, solution). 
samples. The mixture of Hank's solution, $0.5 \mathrm{ng} / \mathrm{mL}$ of simvastatin, and $15 \mathrm{ng} / \mathrm{mL}$ of amlodipine was used as the electrolyte solution. The EIS measurements were accomplished in potentiostatic mode, in the range of frequency from $100 \mathrm{kHz}$ to $10 \mathrm{MHz}$ and the number of frequencies of 50 . Linear polarization tests were conducted at a scan rate of $1 \mathrm{mV} / \mathrm{s}$ in the range from $-0.5 \mathrm{~V}$ to $5 \mathrm{~V} / \mathrm{SC}$.

\section{RESULTS}

\section{1) Surface Characteristic by SEM and EDS Result}

Morphology of the anodized Ti-6Al-4V alloy in cross-section and the relative atomic concentrations of alloying in atom $\%$ as observed by SEM and EDS in Figure 1. While polishing scratches were seen on the surface, they may otherwise have been unmarked. The thickness of the oxide layers without or with thiourea was found to be different with different voltage, time, and solution.

EDX analysis of surface Ti-Al-V alloys (on right side) showed high peaks for titanium and oxide in Figure 1. A, C, E, F, G, and H, but no oxide appeared in Figure 1. B and D with voltage of $3 \mathrm{v}$ for both 1 and 2 hours and used a mixture of $\mathrm{H}_{3} \mathrm{PO}_{4}+\mathrm{NH}_{4} \mathrm{~F}$ and thiourea solution. This demonstrated that the surface oxide's chemical composition of test implants that titanium was primarily composed of incorporated into the $\mathrm{TiO}_{2}$ matrix. The relative atomic concentrations of oxygen $(\mathrm{O})$ and titanium (Ti) at the surface of test were $3 \mathrm{~V}, 1 \mathrm{~h}, \mathrm{H}_{3} \mathrm{PO}_{4}+\mathrm{NH}_{4} \mathrm{~F}$ $=16.54 \% \mathrm{O}$ and $80.31 \% \mathrm{Ti} ;$ B. $3 \mathrm{~V}, 1 \mathrm{~h}, \mathrm{H}_{3} \mathrm{PO}_{4}+\mathrm{NH}_{4} \mathrm{~F}+$ Thiourea $=90.44 \%$ Ti; C. $3 \mathrm{~V}, 2 \mathrm{~h}, \mathrm{H}_{3} \mathrm{PO}_{4}+\mathrm{NH}_{4} \mathrm{~F}=19.77 \% \mathrm{O}$ and $77.98 \% \mathrm{Ti}$; D. $3 \mathrm{~V}, 1 \mathrm{~h}, \mathrm{H}_{3} \mathrm{PO}_{4}+\mathrm{NH}_{4} \mathrm{~F}+$ Thiourea $=92.72 \%$ Ti; E. $12 \mathrm{~V}, 1 \mathrm{~h}, \mathrm{H}_{3} \mathrm{PO}_{4}+\mathrm{NH}_{4} \mathrm{~F}=26.58 \% \mathrm{O}$ and $70.59 \% \mathrm{Ti} ; \mathbf{F}$. $12 \mathrm{~V}, 1 \mathrm{~h}, \mathrm{H}_{3} \mathrm{PO}_{4}+\mathrm{NH}_{4} \mathrm{~F}+$ Thiourea $=22.16 \% \mathrm{O}$ and $75.34 \%$ Ti. G. $12 \mathrm{~V}, 2 \mathrm{~h}, \mathrm{H}_{3} \mathrm{PO}_{4}+\mathrm{NH}_{4} \mathrm{~F}=37.94 \% \mathrm{O}$ and $54.55 \% \mathrm{Ti}$; and H. $12 \mathrm{~V}, 2 \mathrm{~h}, \mathrm{H}_{3} \mathrm{PO}_{4}+\mathrm{NH}_{4} \mathrm{~F}+$ Thiourea $=32.78 \% \mathrm{O}$ and $44.12 \%$ Ti.

The oxide thicknesses can be seen in Table 1. It suggests the distribution of individual elements indicated the presence of titanium in the titanium oxide layer. From Table 1, it reveals that sample with voltage $12 \mathrm{~V}$ during 2 hours time coating with $\mathrm{H}_{3} \mathrm{PO}_{4}+\mathrm{NH}_{4} \mathrm{~F}$ solution has the thickest oxide layer compared to other samples (approximate 23 to $25 \mu \mathrm{m}$ ).

Analysis of surface morphology revealed the porous surface nature of the test implants and the controls' nonporous surface structure (Figure. 2 and 3 ). The morphology structure of sample $3 \mathrm{~V}$ with $\mathrm{H}_{3} \mathrm{PO}_{4}+\mathrm{NH}_{4} \mathrm{~F}$ solution was acquired from SEM as described in Figure 2. As can be seen, the structure of the Ti-6Al-4V is not changed (there is no pores structure on the surface). However, Any white dots are scattered around the surface, signaling the forming of the oxide layer. From table 1, however, since the oxide film relatively thin, there is no significant appearance when it was observed from the side. The almost same morphology structure appeared on the sample for 2 hours (Figure 2.B), but slightly covered in white thin layer.
TABLE 1. THICKNESS OF $\mathrm{TiO}_{2}$ LAYER AT DIFFERENT POTENTIAL, TIME AND SOLUTION

\begin{tabular}{|c|c|c|c|}
\hline $\begin{array}{c}\text { Voltage } \\
\text { (V) }\end{array}$ & $\begin{array}{c}\text { Time } \\
\text { (Hours) }\end{array}$ & Solution & $\begin{array}{c}\text { Thickness } \\
\text { of } \mathrm{TiO}_{2} \text { Layer } \\
(\mu \mathrm{m})\end{array}$ \\
\hline \multirow[t]{2}{*}{3} & 1 & $\begin{array}{c}1 \mathrm{M} \mathrm{H}_{3} \mathrm{PO}_{4} \\
+1 \mathrm{M} \mathrm{NH}_{4} \mathrm{~F}\end{array}$ & $1.4-4.2$ \\
\hline & 1 & $\begin{array}{c}1 \mathrm{M} \mathrm{H}_{3} \mathrm{PO}_{4} \\
+1 \mathrm{M} \mathrm{NH}_{4} \mathrm{~F} \\
+0.5 \mathrm{M} \text { of } \\
\text { thiourea }\end{array}$ & $0.8-2.1$ \\
\hline 3 & 2 & $\begin{array}{c}1 \mathrm{M} \mathrm{H}_{3} \mathrm{PO}_{4} \\
+1 \mathrm{M} \mathrm{NH} \mathrm{NH}_{4} \mathrm{~F}\end{array}$ & $3.0-7.8$ \\
\hline 3 & 2 & $\begin{array}{c}1 \mathrm{M} \mathrm{H}_{3} \mathrm{PO}_{4} \\
+1 \mathrm{M} \mathrm{NH}_{4} \mathrm{~F} \\
+0.5 \mathrm{M} \text { of } \\
\text { thiourea }\end{array}$ & $2.8-5.6$ \\
\hline 12 & 1 & $\begin{array}{c}1 \mathrm{M} \mathrm{H}_{3} \mathrm{PO}_{4} \\
+1 \mathrm{M} \mathrm{NH} \mathrm{NH}_{4} \mathrm{~F}\end{array}$ & $4.4-11.2$ \\
\hline 12 & 1 & $\begin{array}{c}1 \mathrm{M} \mathrm{H}_{3} \mathrm{PO}_{4} \\
+1 \mathrm{M} \mathrm{NH}_{4} \mathrm{~F} \\
+0.5 \mathrm{M} \text { of } \\
\text { thiourea }\end{array}$ & $4.0-8.8$ \\
\hline 12 & 2 & $\begin{array}{r}1 \mathrm{M} \mathrm{H}_{3} \mathrm{PO}_{4} \\
+1 \mathrm{M} \mathrm{NH} \mathrm{NH}_{4} \mathrm{~F}\end{array}$ & $23-25$ \\
\hline 12 & 2 & $\begin{array}{c}1 \mathrm{M} \mathrm{H}_{3} \mathrm{PO}_{4} \\
+1 \mathrm{M} \mathrm{NH}_{4} \mathrm{~F} \\
+0.5 \mathrm{M} \text { of } \\
\text { thiourea }\end{array}$ & $3.4-8.6$ \\
\hline
\end{tabular}
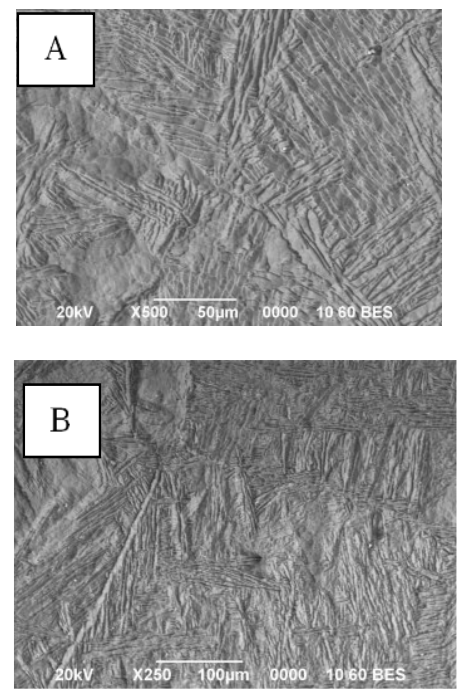

Fig. 2. Surface Morphology of Ti-Al-V Anodize 3V with H3PO4 + NH4F solution during A. 1 hour; B. 2 hours 
The morphology structure of sample $3 \mathrm{~V}$ with $\mathrm{H}_{3} \mathrm{PO}_{4}+$ $\mathrm{NH}_{4} \mathrm{~F}$ solution was acquired from SEM as described in Figure 2. As can be seen, the structure of the Ti-6Al-4V is not changed (there is no pores structure on the surface). However, Some white dots are spread along the surface, indicating the formation of the oxide layer. From table 1, since the oxide film relatively thin, there is no significant appearance when it was observed from the side. The almost same morphology structure appeared on the sample for 2 hours (Figure 2.B), but slightly covered in a white thin layer.
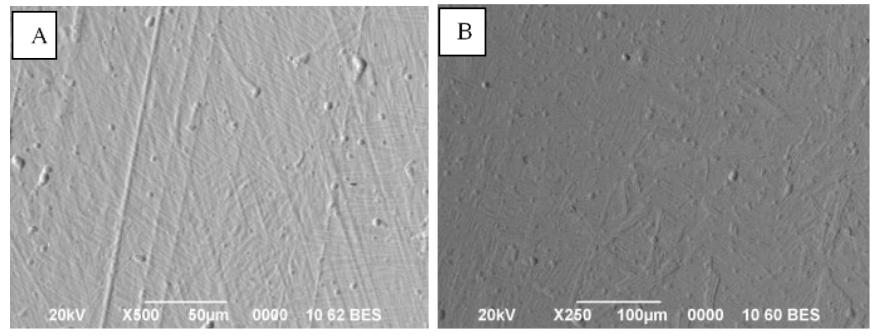

Fig. 3. The Surface Morphology of Ti-Al-V Anodize $12 \mathrm{~V}$ with $\mathrm{H}_{3} \mathrm{PO}_{4}+$ $\mathrm{NH}_{4} \mathrm{~F}$ solution during A. 1 hour; B. 2 hours

2)

\section{Electrochemical Measurement}

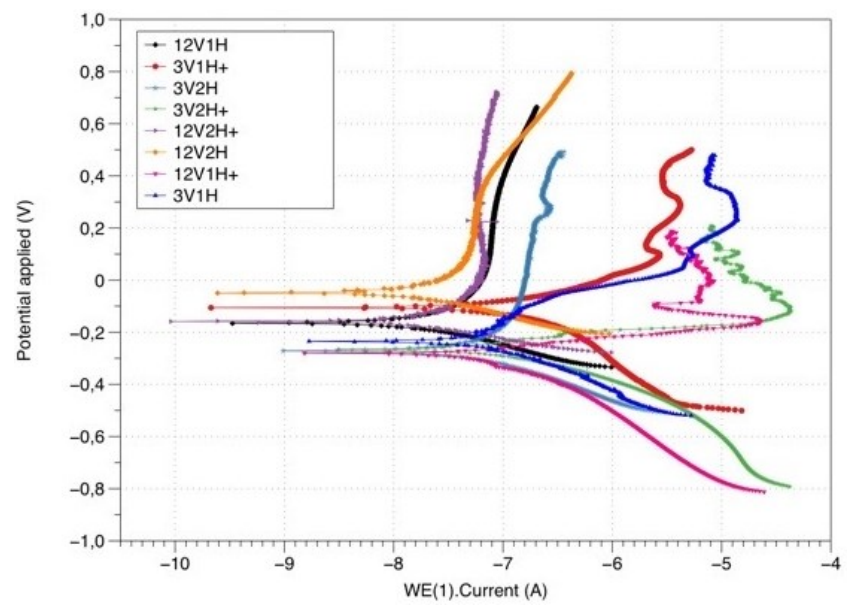

Fig. 4. Potentiodynamic Polarization Curve of Ti $-6 \mathrm{Al}-4 \mathrm{~V}$ in the mixture of mixture of Hank's solution $+0.5 \mathrm{ng} / \mathrm{mL}$ of simvastatin $+15 \mathrm{ng} / \mathrm{mL}$ of

TABLE 2. CORROSION PARAMETERS OF ANODIZED Ti-6Al-4V OBTAINED FROM POTENTIODYNYMIC POLARIZATION CURVES

\begin{tabular}{cccc}
\hline \hline Group & $\begin{array}{c}\boldsymbol{E}_{\text {corr }} \\
(\mathbf{V} \text { vs } \\
\mathbf{A g} / \mathbf{A g C l})\end{array}$ & $\begin{array}{c}\boldsymbol{I}_{\text {corr }} \\
\left(\mathbf{A} / \mathbf{c m}^{2}\right)\end{array}$ & $\begin{array}{c}\text { Corrosion Rate } \\
(\mathbf{m m} / \mathbf{y e a r})\end{array}$ \\
\hline 3V1H & -0.23508 & $2.88 \times 10^{-7}$ & $25.28 \times 10^{-4}$ \\
\hline $\mathbf{3 V 1 H +}$ & -0.10551 & $3.31 \times 10^{-7}$ & $29.076 \times 10^{-4}$ \\
\hline $\mathbf{3 V 2 H}$ & -0.27173 & $1.44 \times 10^{-7}$ & $12.61 \times 10^{-4}$ \\
\hline $\mathbf{3 V 2 H +}$ & -0.26651 & $1.71 \times 10^{-7}$ & $15.06 \times 10^{-4}$ \\
\hline $\mathbf{1 2 V 1 H}$ & -0.21643 & $4.5 \times 10^{-8}$ & $3.95 \times 10^{-4}$ \\
\hline $\mathbf{1 2 V 1 H}+$ & -0.28002 & $7.32 \times 10^{-8}$ & $6.43 \times 10^{-4}$ \\
\hline $\mathbf{1 2 V 2 H}$ & - & $2.56 \times 10^{-8}$ & $2.24 \times 10^{-4}$ \\
\hline $\mathbf{1 2 V 2 H}+$ & -0.15884 & $3.4 \times 10^{-8}$ & $2.99 \times 10^{-4}$ \\
\hline \hline
\end{tabular}

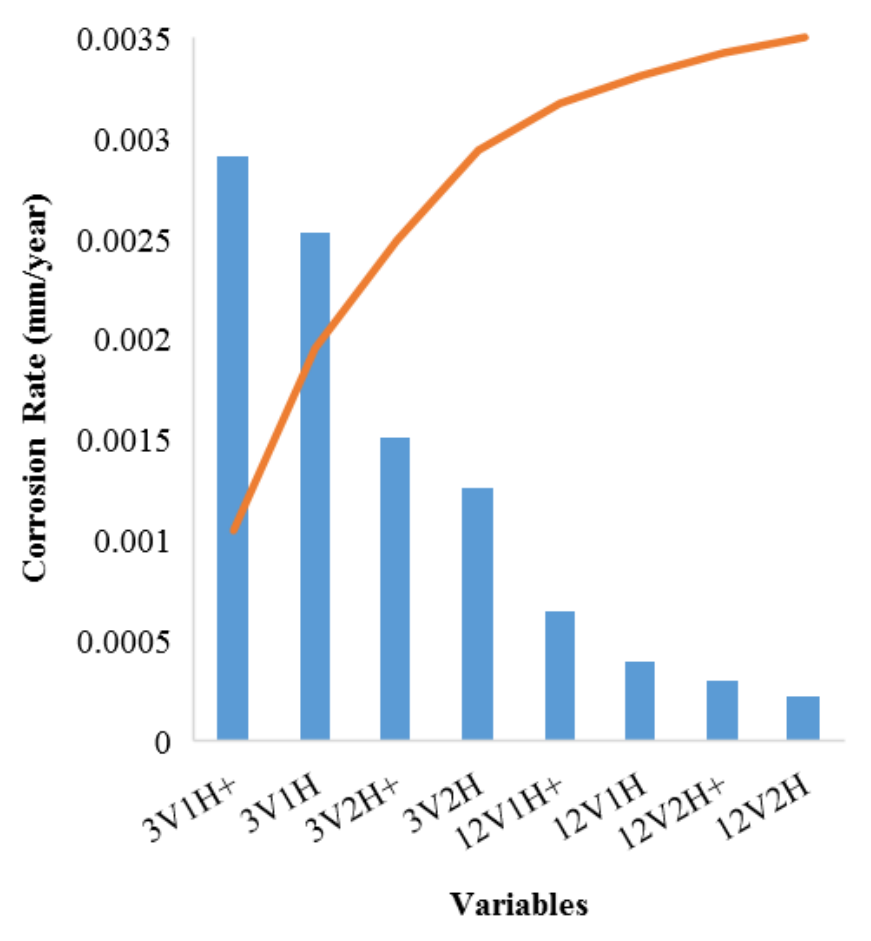

Fig. 5. Corrosion Rate Graph of Ti $-6 \mathrm{Al}-4 \mathrm{~V}$ in the mixture of mixture of Hank's solution $+0.5 \mathrm{ng} / \mathrm{mL}$ of simvastatin $+15 \mathrm{ng} / \mathrm{mL}$ of amlodipine at

Potentiodynamic polarization curves of anodized Ti-6Al$4 \mathrm{~V}$ with different variables showed in Figure 4. Media testing was in the mixture of Hank's solution, $5 \mu \mathrm{L}$ simvastatin and 15 $\mu \mathrm{L}$ amlodipine. Based on the obtained curves, the corrosion parameters such as corrosion potential $\left(E_{\text {corr }}\right)$, current density $\left(I_{\text {corr }}\right)$, and the corrosion rate $(\mathrm{CR})$ are presented in Table 2 . The corrosion parameters are necessary to examine the capability of corrosion resistance [22]. From table 2, it reveals that the 
corrosion resistance of sample $12 \mathrm{~V}$ during $2 \mathrm{H}$ without addition thiourea $(12 \mathrm{~V} 2 \mathrm{H})$ is the highest compared to other samples. It is indicated from its wider passive region. It also possesses the lowest value of $I_{\text {corr }}\left(2.56 \times 10^{-8} \mathrm{~A} / \mathrm{cm}^{2}\right) . I_{\text {corr }}$ value describes the corrosion rate of the substrates, hence the higher the value of the $I_{\text {corr }}$, the higher the corrosion rate is [23]. Sample with potetial $3 \mathrm{~V}$ during $1 \mathrm{H}$ with adddition thiourea $(3 \mathrm{~V} 1 \mathrm{H}+)$ also has the highest corrosion rate among all anodized samples. The breakdown found on pore and rough surface [25]. The current will pass and the oxide will continue to spread as long as the electric field has enough energy to drive the ions across the oxide films [26]. Samples anodized at $3 \mathrm{~V}$ did not get enough energy to breakdown the oxide films, and therefore, only the creation of a thin oxide film has occurred. On the contrary, samples anodized at $12 \mathrm{~V}$ inhibit higher electrical fields. Therefore, they have enough energy to break the barrier layers
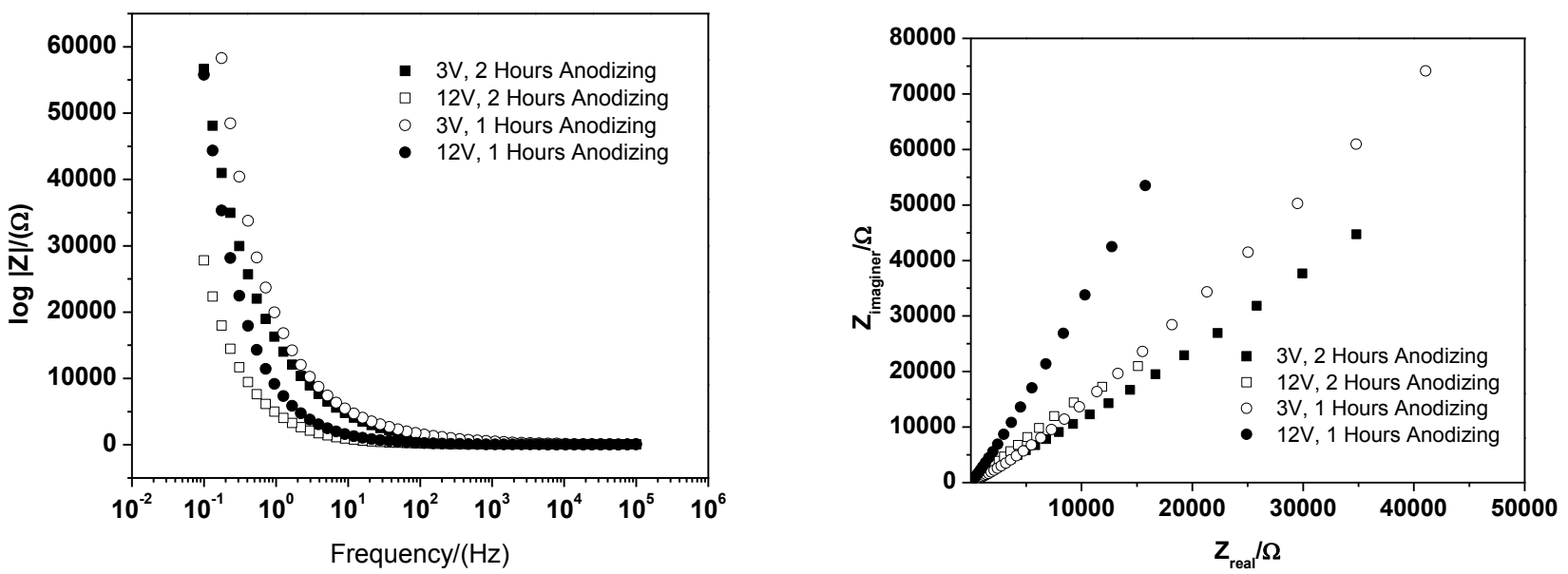

Fig. 6. Potentiostatic EIS data of Bode plot of Ti in the mixture of Hank's solution $+0.5 \mathrm{ng} / \mathrm{mL}$ of simvastatin $+15 \mathrm{ng} / \mathrm{mL}$ of amlodipine at different

graph comparison of corrosion rate can be seen in Figure 5.

EIS study has been carried out for a better understanding of the fundamental or bassist aspects of the corrosion phenomenon of a metallic system in an aqueous corrosive environment. From Figure 6, the impedance spectra of anodized Ti6Al4V with various anodization potential and time presented as a bode plot was shown in figure 1 . It can be seen that between $100 \mathrm{~Hz}-100$ $\mathrm{kHz}$, the absolute value of impedance spectra is independent of frequency. A significant variation of the absolute value of impedance spectra was observed below $100 \mathrm{~Hz}$. These results indicate the effects of applied potential and anodization time on surface corrosion behavior of Ti6Al4V.

\section{Discussion}

To determine the development of the oxide layer on the surface of Ti-6Al-4V and the ability to resist by corrosion environment by anodizing method at low potential at 3 and 12 $\mathrm{V}$, properties of oxidized was measured and analyzed by SEM, EDS and electrochemical measurement.

Samples anodized at the potential of $3 \mathrm{~V}$ did not affect the base metals much comparing with the samples anodized at 12 $\mathrm{V}$, as can be seen in Figure 1.A to 1.H. The applied voltage adds to the frequency of the field of electric through the oxide layer, thereby influencing the electrolyte ion movement [24]. Higher voltage encourages a higher electrical field, which makes it easier during the initial anodization stage to induce fields for and develop some shallow pits. Pores would ideally form at such places as pits or cracks when the weakening of the oxide layer allowed the current layer to pass [27].

Under the same condition ( $\mathrm{pH}$, anodization period, applied voltage, and others.) the different electrolyte can alter the morphology of the $\mathrm{TiO}_{2}$ films. The composition of electrolytes also affects the electrical fields, alike to the applied potential. Some electrolytes have different ionic conductivity inside an electrochemical cell that activates various electrical fields [28]. Comparing all the obtained images from the SEM, sample anodized at the electrolytes containing thiourea generating fewer amounts of white spots as well as fewer shallow hole-like formation (for samples anodized at $12 \mathrm{~V}$ ). SEM images showed the thickness of the samples (Figure 1.G and Figure 1.H) also resulting thinner oxide films development on samples anodized in thiourea containing electrolytes. The additive substances seemed inhibition of the film of oxide formed on the titanium surface, therefore, thinner films were generated. On the samples anodized at $12 \mathrm{~V}$ also demonstrate the decreasing amounts of shallow pits, which indicated that the electrical fields within the electrolyte had decreased. The smaller electrical fields would slow down the ion movements, thus harder to induce the breakdown fields on the surface during the first stage of anodization. Meanwhile, when the thiourea content is low, the heavy oxidation of acid in the electrolyte played a prominent role in metal degradation, leading to the dissolution of a huge number of walls with openings and the formation of pits or 
oxidation occurs [29]. The efficacy of an electrolyte for titanium anodic oxidation depends primarily on the capacity of the electrolyte to dissolve the anodic element [30].

Surface morphology structures of sample $12 \mathrm{~V}$ with $\mathrm{H}_{3} \mathrm{PO}_{4}+$ $\mathrm{NH}_{4} \mathrm{~F}$ solution was presented by Figure 3, during 1 hour (Figure 3.A) and during 2 hours (Figure 3.B), respectively. Here, the surface structure changes a bit, in contrast with the previous images. There is the development of shallow pits on some area. There are also white spots appear on the surface of the metals that covered the pits which indicated the oxide film formation. If the oxide forms on the surface, it starts to increase in both its thickness and defect dimension. Therefore, electron-current rises, and the evolution of oxygen takes place on defects such as pores. This contributes to chemical oxidation in the pores [31][32].

The period of anodization should influence the length of pits or pores [24]. Quick coating time encourages greater pore size formation and that maybe that the primary element is the dissolution mechanism. Longer coating times cause the mechanism of deposition to prevail over the mechanism of dissolution, leading to fewer and smaller pores (Figure 2 and Figure 3). Deposition becomes more important than dissolution for coatings produced from intermediate ages. A pattern related to the difference in thickness with coating times also exhibits a surface defect. Duration of 2 hours gives surfca greater coverage and a further improvement in coating time contributes to lower defect values.

Anodization is the oxidation of metals by creating an electrical field at the interface of metal/electrolytes with such electrolytes. It is possible to produce nanofeatures with different morphologies and sizes on metallic surfaces through anodization, as previously mentioned. On titanium surfaces, the electrical potential applied during the anodization process increases the thickness of this natural oxide layer. Until the voltage is applied to titanium alloys connected to the anode of an electrochemical cell, an oxidation reaction will start at the metal/metal oxide interface The applied voltage would decrease as a result of having a higher electrical resistivity than the underlying titanium substrate via the oxide layer that forms on the surface [33].

The Ecore value or corrosion potential is useful for predicting and detecting actual and expected corrosion risk and for monitoring electrochemical reactions causing corrosion [34]. The number of corrosion potential $E_{\text {corr }}$ reflects the stability of the oxide layer of the metal. For passivity to be given, stability is necessary. Passivity is a corrosion control technique in which the oxidation film forms a continuous coating on the metal surface that prevents further corrosion [34]. The greater number of $E_{\text {corr }}$ value implies the more stable the oxide layer (more inert surface or less reactive) [35] [36]. The $E_{\text {corr }}$ value of sample $12 \mathrm{~V} 1 \mathrm{H}+$ and sample $12 \mathrm{~V} 1 \mathrm{H}$ is the greatest than other samples, which implies the outstanding resistance to the corrosion. On the graphs, it is portrayed with the more positive value on $y$ axis.
Potentiostatic EIS data of Bode plot of Ti in the mixture of Hank's solution $+0.5 \mathrm{ng} / \mathrm{mL}$ of simvastatin $+15 \mathrm{ng} / \mathrm{mL}$ of amlodipine at different potentials and time without thiourea in the coating solution shown in Figure 6, as the fundamental aspects of corrosion phenomenon of a metallic system in an aqueous corrosive environment. The highest absolute value of impedance spectra was observed for $12 \mathrm{~V}$, and 2 hours anodization. In the kinetic frame of experiment, it can be explained that higher potential and longer anodization process produced thicker oxide film on Ti6Al4V. It is impossible to see completed semicircle in anodize Ti6Al4V over all frequency by Nyquist plot due to highly resistivity surface. Anodization of Ti6Al4V in the mixture of $1 \mathrm{M}$ of $\mathrm{H}_{3} \mathrm{PO}_{4}+1 \mathrm{M}$ of $\mathrm{NH}_{4} \mathrm{~F}$ without thiourea solution, produces Ti6Al4V with higher charge transfer resistance and good corrosion resistance. Many studies have shown that corrosion resistance of commercially pure titanium has improved after anodization and increased oxide layer thickness has tended to decrease the chance of corrosion [37]. Although there are separate results in the anodizationtreated Ti-6Al-4V alloy studies [17]. Most earlier experiments, however, based on low voltage or current and used either galvanostatic or potentiostatic anodization in various electrochemical techniques.

\section{Conclusion}

Oxide coatings were developed by anodization method on Ti$6 \mathrm{Al}-4 \mathrm{~V}$ at low potential $3 \mathrm{~V}$ and $12 \mathrm{~V}$ from the mixture of $1 \mathrm{M}$ $\mathrm{H}_{3} \mathrm{PO}_{4}, 1 \mathrm{M} \mathrm{NH} \mathrm{NH}_{4}$ with and without Thiourea electrolyte. Coating time varied from 1 and $2 \mathrm{~h}$. On the surface, titanium oxide is formed and avoids degradation of the high corrosion rate and subsequent re-deposition of it. In solution $1 \mathrm{M} \mathrm{H}_{3} \mathrm{PO}_{4}$, $1 \mathrm{M} \mathrm{NH}_{4} \mathrm{~F}$ without Thiourea electrolyte, the width, surface defect and partially covering white increased with increased exposure time at $2 \mathrm{~h}$. Ti-6Al- $4 \mathrm{~V}$ coated with $12 \mathrm{~V}$ during $2 \mathrm{~h}$ in the mixture of $1 \mathrm{M} \mathrm{H}_{3} \mathrm{PO}_{4}, 1 \mathrm{M} \mathrm{NH} \mathrm{NH}_{4} \mathrm{~F}$ without Thiourea electrolyte showed the best corrosion resistance in the mixture of Hank's solution, $0.5 \mathrm{ng} / \mathrm{mL}$ of simvastatin and $15 \mathrm{ng} / \mathrm{mL}$ of amlodipine. This is due to its greater thickness and the lowest existence of corrosion resistance. Modern modified titanium surfaces can be considered a powerful tool at the present level of expertise, particularly in those conditions where the osseointegration rate is lower. Since the debate on this topic is only addressed in the Ti-6Al-4V context, implant surfaces must only indicate one of the different variables that can affect the final output of an implant. In order to limit all possible risk factors for the occurrence of biomechanical and biological complications, careful selection for implant treatment should always be given a great deal of attention.

\section{ACKNOWLEDGMENT}

The authors would like to acknowledge the financial support from RISET IPTEKES, Ministry of Health Republic Indonesia. The authors would also like to thanks the Research Center of Metallurgy and Materials LIPI/BRIN for generously providing the use of test instruments. 


\section{REFERENCES}

[1] S. Minagar, J. Wang, C. C. Berndt, E. P. Ivanova, and C. Wen, "Review Article Cell response of anodized nanotubes on titanium and titanium alloys," vol. 110101974, pp. 1-14, 2013, doi: 10.1002/jbm.a.34575.

[2] Y. X. Leng, J. Y. Chen, P. Yang, H. Sun, and N. Huang, "Structure and properties of passivating titanium oxide films fabricated by DC plasma oxidation," Surf. Coatings Technol., vol. 166, no. 2-3, pp. 176-182, 2003 , doi: 10.1016/S0257-8972(02)00780-6.

[3] Z. Abdolldhi, a a Ziaee M., and A. Afshar, "Investigation of Titanium Oxide Layer in Thermal-Electrochemical Anodizing of Ti6A14V Alloy.," Proc. World Acad. Sci. Eng. Technol., vol. 46, no. 8, pp. 523-526, 2008.

[4] C. Y. Chiang et al., "Formation of TiO2 nano-network on titanium surface increases the human cell growth," Dent. Mater., vol. 25, no. 8, pp. 1022 1029, 2009, doi: 10.1016/j.dental.2009.03.001.

[5] Y. Otawara, K. Ogasawara, H. Kashimura, Y. Kubo, A. Ogawa, and K. Watanabe, "Mechanical characteristics and surface elemental composition of a Yasargil titanium aneurysm clip after long-term implantation: Technical note," J. Neurosurg., vol. 112, no. 6, pp. 12601262, 2010, doi: 10.3171/2009.9.JNS09827.

[6] L. Mohan, C. Anandan, and N. Rajendran, "Electrochemical behavior and effect of heat treatment on morphology, crystalline structure of selforganized $\mathrm{TiO} 2$ nanotube arrays on $\mathrm{Ti}-6 \mathrm{Al}-7 \mathrm{Nb}$ for biomedical applications," Mater. Sci. Eng. C, vol. 50, pp. 394-401, 2015, doi: 10.1016/j.msec.2015.02.013.

[7] E. S. Kim, Y. H. Jeong, H. C. Choe, and W. A. Brantley, "Formation of titanium dioxide nanotubes on Ti-30Nb-x Ta alloys by anodizing," Thin Solid Films, vol. 549, pp. 141-146, 2013, doi: 10.1016/j.tsf.2013.08.058.

[8] V. S. Saji, H. C. Choe, and W. A. Brantley, "Nanotubular oxide layer formation on Ti-13Nb-13Zr alloy as a function of applied potential," $J$. Mater. Sci., vol. 44, no. 15, pp. 3975-3982, 2009, doi: 10.1007/s10853009-3542-4.

[9] R. M. Urban, J. J. Jacobs, M. J. Tomlinson, J. Gavrilovic, J. Black, and M. Peoc'h, "Dissemination of wear particles to the liver, spleen, and abdominal lymph nodes of patients with hip or knee replacement," J. Bone Jt. Surg. - Ser. A, vol. 82, no. 4, pp. 457-477, 2000, doi: 10.2106/00004623-200004000-00002.

[10] C. Aparicio, F. Javier Gil, C. Fonseca, M. Barbosa, and J. A. Planell, "Corrosion behaviour of commercially pure titanium shot blasted with different materials and sizes of shot particles for dental implant applications," Biomaterials, vol. 24, no. 2, pp. 263-273, 2003, doi: 10.1016/S0142-9612(02)00314-9.

[11] K. Yokoyama, T. Ichikawa, H. Murakami, Y. Miyamoto, and K. Asaoka, "Fracture mechanisms of retrieved titanium screw thread in dental implant," Biomaterials, vol. 23, no. 12, pp. 2459-2465, 2002, doi: 10.1016/S0142-9612(01)00380-5.

[12] M. Annunziata and L. Guida, "The Effect of Titanium Surface Modifications on Dental Implant Osseointegration," Front. Oral Biol., vol. 17, pp. 62-77, 2015, doi: 10.1159/000381694.

[13] S. Paul and K. Yadav, "Corrosion behavior of surface-treated implant Ti$6 \mathrm{Al}-4 \mathrm{~V}$ by electrochemical polarization and impedance studies," $J$. Mater. Eng. Perform., vol. 20, no. 3, pp. 422-435, 2011, doi: 10.1007/s11665-010-9691-4

[14] P. Schüpbach et al., "The human bone-oxidized titanium implant interface: A light microscopic, scanning electron microscopic, backscatter scanning electron microscopic, and energy-dispersive X-ray study of clinically retrieved dental implants," Clin. Implant Dent. Relat. Res., vol. 7, no. SUPPL. 1, pp. s36-s43, 2005, doi: 10.1111/j.17088208.2005.tb00073.x.

[15] M. Ali, A. Taib, G. O. Kawamura, A. Matsuda, and M. Jaafar, "Synthesis of TiO 2 Nanotube Arrays in $\mathrm{NaOH}$ added Ethylene Glycol Electrolyte and the Effect of Annealing Temperature on the Nanotube Arrays to their Photocurrent Performance," vol. 701, pp. 28-32, 2016, doi: 10.4028/www.scientific.net/KEM.701.28.
[16] A. Karambakhsh, A. Afshar, and P. Malekinejad, "Corrosion Resistance and Color Properties of Anodized Ti-6Al-4V," vol. 21, no. January, pp. 121-127, 2012, doi: 10.1007/s11665-010-9791-1.

[17] R. Narayanan and S. K. Seshadri, "Phosphoric acid anodization of Ti $6 \mathrm{Al}-4 \mathrm{~V}-$ Structural and corrosion aspects," vol. 49, pp. 542-558, 2007 , doi: 10.1016/j.corsci.2006.06.021.

[18] V. Babuska et al., "Proliferation of Osteoblasts on Laser-Modified Nanostructured Titanium Surfaces," 2018, doi: 10.3390/ma11101827.

[19] [20] Misriyani, A. W. Wahab, P. Taba, and J. Gunlazuardi, "Effect of anodizing time and annealing temperature on photoelectrochemical properties of anodized $\mathrm{TiO} 2$ nanotube for corrosion prevention application," Indones. J. Chem., vol. 17, no. 2, pp. 219-227, 2017, doi: $10.22146 / \mathrm{ijc} .24183$

[20] Q. Sui, P. Li, K. Wang, X. Yin, L. Liu, and Y. Zhang, "Effect of Build Orientation on the Corrosion Behavior and Mechanical Properties of Selective Laser Melted Ti-6Al-4V," MDPI, 2019.

[21] V. A. R. Barão, M. T. Mathew, W. G. Assunção, J. C. C. Yuan, M. A. Wimmer, and C. Sukotjo, "Stability of cp-Ti and Ti-6Al-4V alloy for dental implants as a function of saliva $\mathrm{pH}$ - an electrochemical study," Clin. Oral Implants Res., vol. 23, no. 9, pp. 1055-1062, 2012, doi: 10.1111/j.1600-0501.2011.02265.x.

[22] D. Regonini, C. R. Bowen, A. Jaroenworaluck, and R. Stevens, “A review of growth mechanism , structure and crystallinity of anodized TiO 2 nanotubes," Mater. Sci. Eng. R, vol. 74, no. 12, pp. 377-406, 2013, doi: 10.1016/j.mser.2013.10.001.

[23] M. İzmir and B. Ercan, "Anodization of titanium alloys for orthopedic applications," Front. Chem. Sci. Eng., vol. 13, no. 1, pp. 28-45, 2019, doi: 10.1007/s11705-018-1759-y.

[24] X. Liu, P. K. Chu, and C. Ding, "Surface modification of titanium , titanium alloys , and related materials for biomedical applications," vol. 47, no. 2004, pp. 49-121, 2005, doi: 10.1016/j.mser.2004.11.001.

[25] D. Regonini, C. R. Bowen, A. Jaroenworaluck, and R. Stevens, “A review of growth mechanism, structure and crystallinity of anodized TiO2 nanotubes," Mater. Sci. Eng. R Reports, vol. 74, no. 12, pp. 377-406, 2013, doi: 10.1016/j.mser.2013.10.001.

[26] İ. Merve and B. Ercan, "Anodization of titanium alloys for orthopedic applications," pp. 1-18, 2018.

[27] Y. Wang, R. Guo, X. Zhou, and G. Hu, "Experimental investigation on optimal anodising parameters of nanopore preparation process on the stainless steel surface," Corros. Eng. Sci. Technol., vol. 0, no. 0, pp. 1-7, 2020, doi: 10.1080/1478422X.2020.1747759.

[28] Y. Sul, C. B. Johansson, Y. Jeong, and T. Albrektsson, "The electrochemical oxide growth behaviour on titanium in acid and alkaline electrolytes," vol. 23, pp. 329-346, 2001.

[29] E. Acta and P. Prw-s, "KINETICS ON OXIDE-FILM GROWTH ACID MEDIA *," vol. 16, no. November 1969, pp. 1539-1553, 1971.

[30] "A THEORY FOR BREAKDOWN OF ANODIC OXIDE FILMS ON METALS *," vol. 16, no. October 1969, pp. 1683-1692, 1971.

[31] M. A. S. Mahshid, A. Dolati, M. Goodarzi, "Self-organized titanium oxide nanotubes prepared in phosphate electrolytes: Effect of applied voltage and fluorine concentration," Electrochem. Soc., p. 2015, 2011.

[32] Corrosionpedia, "Corrosion Potential," Corrosionpedia, 2019.

[33] L. Wang and L.-C. Zhang, Developmet and Application of Biomedical Titanium Alloys. Bentham Science Publisher, 2018.

[34] A. Ching et al., "Corrosion behaviour and microstructure of tantalum film on Ti $6 \mathrm{Al} 4 \mathrm{~V}$ substrate by filtered cathodic vacuum arc deposition Corrosion behaviour and microstructure of tantalum fi $\mathrm{lm}$ on Ti6Al4V substrate by fi ltered cathodic vacuum arc deposition," Thin Solid Films, vol. 636, no. May, pp. 54-62, 2017, doi: 10.1016/j.tsf.2017.05.030.

[35] I. S. Park et al., "Effects of anodizing voltage on the anodized and hydrothermally treated titanium surface," Met. Mater. Int., vol. 12, no. 6, pp. 505-511, 2006, doi: 10.1007/BF03027751. 